\title{
ANALISIS DAMPAK RAMADHAN TERHADAP KINERJA IHSG DAN INDEKS SEKTORAL PERIODE 2008 - 2018
}

\author{
Anggi Puspa Pradhini \\ Fadlul Imansyah \\ Magister Manajemen, Kekhususan Manajemen Pasar Modal, \\ Fakultas Ekonomi dan Bisnis, Universitas Indonesia \\ apuspap@gmail.com \\ fadlul.imansyah@gmail.com
}

\begin{abstract}
This research aims to analyze trend of stock volatility during Ramadhan, both on the composite index (IHSG) and sectoral price index. This research employs data ranging from $2008-2018$ accessed from Eikon - Centre of Economic and Business Data Faculty of Economics and Business Universitas Indonesia. In order to analyze whether or not price volatility might differ between Ramadhan and other periods, this research employs Non-Parametric Mann Whitney Test, where the result shows that there is not significant difference of stock price volatility between Ramadhan and other periods, as shown by p-values above error level by $5 \%$. During Ramadhan, the increase in stock price is not as high as those in other periods, even at the same time, trade during Ramadhan tends to be more dynamic (higher variance). In order to analyze trend of stock price during Ramadhan, this research employs ARCH GARCH Model, where healthcare sector is the only that experience significant increase in stock price during Ramadhan along 2008 - 2018. The ARCH coefficient is 0.996, while the GARCH coefficient is 0.128. If analyzed deeper, IHSG return during Ramadhan is not significantly different from other months along 2008 - 2018, even lower. During Ramadhan, the average growth of IHSG return is $-0.04 \%$, while during other periods, the average growth is $0.07 \%$. Nevertheless, the result appears to be different when analyzed using sectoral industry return. According to data processing of the research, it is found that healthcare sector is the only one that is increasing during Ramadhan. Along 2008 - 2018, the increase in return of healthcare sector is $3.21 \%$, while in other periods, it is only increasing by $0.41 \%$. The increase in return of healthcare sector has been mainly driven by the increase in positive expectation of investor due to higher sales performance of firms in healthcare industry. The main sales increase focuses on nutrition product and prescription medication. Therefore, this finding can be a strategic consideration for investor to gain more return upon their portfolio investment.
\end{abstract}

Keywords: $\quad$ Pasar Modal, IHSG, Saham Sektoral, ARCH GARCH JEL Classifications : G1 G110 C580 G120

\section{PENDAHULUAN}

Investasi saham di Indonesia sudah semakin popular di kalangan masyarakat. Dari banyaknya pilihan instrument investasi yang tersedia, berinvestasi di saham menjadi salah satu pilihan. Dengan adanya fasilitas trading online berinvestasi di saham menjadi semakin mudah dan disukai generasi milenial. Selain itu Bursa Efek Indonesia juga menggalakan banyaknya 
program Sekolah Pasar Modal (SPM) untuk semakin mempopulerkan berinvestasi saham ke khayalak luas.

Tak heran sekarang ini jumlah investor yang tercatat di di Bursa Efek Indonesia sudah mencapai lebih dari satu juta investor. Walaupun jumlah ini masih sangat kecil dibandingkan dengan jumlah penduduk Indonesia yang mencapai lebih dari 250 juta penduduk, penulis yakin dengan semakin tingginya kesadaran investasi di kalangan masyarakat jumlah investor di bursa juga akan terus bertambah.

Sebagai Negara yang mayoritas beragama Islam, otomatis banyak investor yang berinvestasi saham juga mayoritas beragama Islam. Bulan Ramadhan menjadi salah satu momen spiritual yang ditunggu oleh umat muslim di seluruh dunia. Semua sektor bisnis yang bergerak di Indonesia pasti akan terpengaruh dengan datangnya bulan Ramadhan.

Ramadhan di Indonesia memiliki sifat yang khas dibandingkan dengan Ramadhan di belahan dunia lain. Sudah menjadi tradisi di Indonesia, di penghujung bulan Ramadhan kebanyakan orang melakukan tradisi mudik yaitu pulang ke kampung halaman untuk menghabiskan Hari Idul Fitri bersama orang tua dan keluarga besar. Tradisi mudik ini disertai dengan hal lainnya seperti memakai baju baru dan menukar uang dalam pecahan kecil seringnya untuk dibagikan kepada anak-anak kecil sehabagai hadiah Lebaran.

Tradisi yang sudah berlangsung selama beberapa dekade ini jelas mempengaruhi perilaku perilaku customer dan diamati secara cermat oleh dunia bisnis. Mall tempat tujuan berbelanja pasti berlomba memberikan diskon, show room mobil dan motor pasti memberikan kemudahan tertentu untuk memfasilitasi pembelian armada baru, tiket bis, kereta api, kapal laut, dan pesawat habis terjual berbulanbulan sebelum bulan Ramadhan itu sendiri datang. Hal ini menimbulkan pertanyaan di benak penulis, apakah datangnya bulan Ramadhan mempengaruhi keputusan investasi yang diambil investor di pasar modal Indonesia?

\section{TINJAUAN PUSTAKA}

Harga saham dikatakan tidak dapat diprediksi dan berjalan berdasarkan teori random walk (Fama, 1970). Namun Jensen pada tahun 1978 menyoroti ketidakkonsistenan EHM sebagai akibat dari banyaknya bukti anomaly yang terjadi di pasar keuangan di seluruh dunia.

Dalam buku The Handbook of Equity, Zack memaparkan banyaknya anomali yang terjadi di market dengan berbagai sebab. Dalam penelitian ini penulis berfokus terhadap anomali musiman yang terjadi di pasar modal.

Penelitian tentang anomali musiman telah lama dilakukan oleh banyak peneliti di banyak negara. Beberapa contoh penelitian anomali musiman dan pemicunya adalah sebagai berikut:

\section{January Effect}

Efek return abnormal di bulan Januari awalnya diteliti oleh Rozeff dan Kinney (1976) yang menyatakan bahwa dari tahun 1904-1974 di bulan Januari saham dari perusahaan berkapitalisasi kecil bisa mengalahkan return dari perusahaan dengan kapitalisasi besar.

Penelitian tentang efek Januari ini terus dilakukan dan mendapatkan hasil terbaru melalui perhitungan S\&P 500 yang dilakukan oleh Rendon dan Ziemba (2007) yang menyatakan bahwa Januari Effect masih berlaku tapi bergeser ke bulan Desember.

\section{Sell in May and Go Away atau Halloween Effect}

Bulan September dan Oktober secara historikal selalu memberikan return yang rendah di pasar modal (Gultekin and Gultekin, 1983 ; Keim and Ziemba, 2000). Penelitian ini menyarankan investor untuk menghindari pasar modal di bulan yang dianggap buruk dan baru kembali 
ke pasar ketika memasuki bulan yang baik.

\section{International January Barometer}

Henzel dan Ziemba (1995b), Easton dan Pinder (2007, dan Stivers, Sun, dan Sun (2009) menemukan bahwa fenomena January Barometer terjadi di banyak market di seluruh dunia. Delapan puluh lima persen return di bulan Januari cenderung positif di pasar Swiss, Eropa, dan Amerika Serikat.

Namun demikian, January Barometer tidak terprediksi dengan baik di beberapa Negara seperti Jepang, Perancis, Spanyol, dan Jerman (Bohl dan Salm, 2010).

\section{Holiday Effect}

Bialkowski, Etabari, dan Wisnieski (2009) meneliti return di pasar modal pada saat bulan Ramadhan di 14 negara muslim pada periode 1989-2007. Hasilnya ditemukan bahwa return stock saat Ramadhan mencapai sembilan kali lebih tinggi dibanding di luar Ramadhan. Penjelasan untuk hal ini menghubungankan antara emosi investor dengan keputusan yang mereka ambil. Di bulan Ramadhan investor cenderung lebih optimis karena di bulan Ramadhan suasana hati investor lebih bahagia, memiliki rasa solidaritas yang tinggi dan sebagai penunjuk identitas sosial bagi umat Islam.

Bahkan Knerr dan Pearl (2008) menyebut Ramadhan sebagai euphoria ringan yang terjadi di kalangan umat Islam setiap tahunnya. Sentimen optimis ini menyebabkan investor memiliki tingkat kepercayaan berlebihan dan peningkatan keinginan mengambil risiko dan memandang investasi sebagai nilai yang relatif lebih tinggi.

\section{Seasonality Calendars}

Canestrelli dan Ziemba (2000) meneliti anomali musiman yang ada di pasar saham Italia dari tahun 1973-1993. Hasilnya menunjukan bahwa efek musiman yang ada di Amerika, Jepang, dan negara lain seperti TOM, holiday effect, weekend effect juga terjadi di Italia.

\section{Political Effects}

Ferguson and Witte (2006) menemukan korelasi antara aktivitas kongres di Amerika dengan return yang didapat di pasar modal. Ternyata pada saat aktivitas kongres meningkat, return yang didapat dari pasar modal menurun dan volatilitas perdagangan meningkat.

Selain kegiatan kongres, sesi pemilihan umum di Amerika ternyata juga memberikan return yang lebih tinggi dari rata-rata dengan puncaknya tercapai pada bulan November di tahun pemilihan presiden (Herbst and Slinkman, 1984).

Selain itu, efek kemenangan partai antara Republik dan Demokrat juga diteliti efeknya terhadap return di pasar modal. Hensel dan Ziemba (1995c, 2000) menemukan bahwa perusahaan dengan $20 \%$ kapitalisasi paling kecil memiliki return yang lebih tinggi ketika kekuasaan Partai Demokrat.

\section{Tun-of-the-Month (TOM) Effects}

Berdasarkan data historis, setiap pergantian bulan, baik perusahaan berkapitalisasi besar dan kecil cenderung mendapatkan return yang tinggi. Merrill (1966), Fosback (1976), dan Hisrch (1986) berpendapat bahwa saham naik pada pergantian bulan. Ariel (1987) melakukan penelitian ini dilakukan di Amerika Serikat dalam kurun waktu tahun 1963-1981.

Penyebab adanya efek TOM sebagian besar dikarenakan adanya penggelontoran uang cash oleh institusi-institusi. Di Amerika Serikat, gaji para pekerja dibayarkan pada akhir bulan sehingga mendorong investor untuk bertransaksi di pasar modal.

Efek TOM ini juga terjadi di Jepang (Ziemba, 1991). Beberapa alasan terjadinya efek TOM di Jepang karena: 1. Kebanyakan gaji dibayarkan pada tanggal 25 di setiap bulan. 2. Adanya kecenderungan window dressing yang dilakukan sehari sebelum pergantian bulan. 3. Perusahaan sekuritas cenderung melakukan pembelian di tiga hari sebelum pergantian bulan. 4. Perusahaan sekuritas besar biasanya mendapatkan 
tekanan beli yang cukup tinggi pada akhir pergantian bulan. Kecenderungan untuk masuk pasar dan melakukan pembelian ini biasanya terjadi selama 7-10 hari. 5. Perusahaan reksa dana dan saham kepemilikan pegawai biasanya mendapat dana segar di sekitar akhir bulan mengikuti cairnya gaji para pegawai. 6. Investor individu cenderung membeli reksa dana di akhir bulan mengikuti tanggal gaji yang diterima dari kantor.

\section{Open/Close Daily Trade on the Open}

Branch and Ma (2006) menganalisi saham NYSE, AMEX, dan NASDAQ pada tahun 1994 dan 2005 dan menemukan adanya autokorelasi negatif yang sangat kuat antara overnight return dan intraday return. Mereka bahkan membuat hipotesis lebih jauh dengan menyatakan bahwa penyebab anomaly ini terkait dengan perilaku market maker dan strate dan insentif yang akan mereka lakukan berdasarkan harga penutupan di hari sebelumnya.

Branch and Ma (2006) menganggap hanya market maker yang bisa memanfaatkan anomaly ini karena diuntungkan informasi mereka yang mengetahui order yang masuk di malam hari sebelum pasar modal buka. Untuk investor retail, hal yang bisa dilakukan hanyalah menghindari memasukan order yang akan dieksekusi ketika pembukaan pasar.

\section{Weather: Sun, Rain, Snow, Moon, and the Stars}

Psikolog telah mendokumentasikan korelasi antara matahari dan perilaku selama beberapa dekade. Ketika hari cerah karena ada sinar matahari dikaitkan dengan pemberian tip (Rind, 1996) dan kurangnya sinar matahari cenderung menimbulkan depresi (Eagles, 1994) dan bunuh diri (Tietjen dan Kripe, 1994).

Kaitannya dengan pasar modal, saat matahari bersinar investor cenderung lebih optimis dan lebih cenderung membeli saham sehingga harga saham cenderung untuk naik (Hirschleifer dan Shumway,
2003). Penelitian ini dilakukan di 26 negara dari tahun 1982-1997. Kondisi cuaca yang lain seperti hujan dan turunnya salju tidak berkaitan dengan return saham.

Terinspirasi dari berbagai penelitian tentang anomali musiman di pasar saham yang sudah dilakukan sebelumnya, dalam penelitian ini penulis meneliti kinerja IHSG dan index sektoran pada saat bulan Ramadhan dari tahun 2008-2018.

\section{Data}

Dalam penelitian ini, data yang digunakan adalah data harga saham IHSG maupun harga saham sektoral. Data yang digunakan adalah data kinerja harga saham pada rentang periode 2008 hingga 2018, di mana data bersumber dari data Eikon yang diakses dari Pusat Data Ekonomi dan Bisnis (PDEB), Fakultas Ekonomi dan Bisnis Universitas Indonesia. Dalam penelitian ini, sektor-sektor yang digunakan sebagai analisis mencakup Energy, Materials, Consumer Cyclical, Consumer Non-Cyclical, Healthcare, Technology, Telecommunication, dan Utilities.

Secara umum, teknik pemilihan sampel data pada suatu penelitian dapat digolongkan menjadi dua cara, yaitu probability sampling dan non-probability sampling. Probability sampling adalah teknik pengambilan sampel penelitian dengan memberikan kesempatan atau peluang yang sama untuk dijadikan sampel kepada setiap elemen populasi. Sedangkan non-probability sampling adalah teknik pengambilan sampel yang tidak memberikan peluang atau kesempatan yang sama kepada setiap elemen populasi untuk dijadikan sampel penelitian.

Dalam penelitian ini, teknik pemilihan sampel data yang digunakan adalah nonprobability sampling dengan menggunakan judgement sampling, yaitu metode yang digunakan ketika periset memilih anggota sampel untuk memenuhi kriteria-kriteria tertentu (Cooper dan Schindler, 2008). Dalam penelitian ini, sampel yang digunakan adalah unit pada seluruh sampel yang ada di 
dalam populasi. Dalam penelitian ini, seluruh perusahaan yang listed di bursa menjadi obyek pengamatan dalam penelitian ini, di mana analisis yang dilakukan dilakukan dalam dua tahap, yang pertama adalah analisis pada seluruh sampel, dan yang kedua adalah analisis berdasarkan kategori industri.

Jenis data yang digunakan dalam penelitian ini adalah data time series. Data time series merupakan data yang memiliki pergerakan saham pada masing-masing sektor tersebut, selama rentang periode 2008 hingga 2018. Secara mendetail, data yang digunakan di dalam penelitian ini disajikan pada tabel di bawah ini.

Berdasarkan hasil pengolahan data di atas, saham sektoral yang cukup dinamis dalam jika dibandingkan sektor yang lainnya adalah healthcare dan sektor consumer non-cyclical.

Tabel 1. Data Penelitian

\begin{tabular}{llc}
\hline \multicolumn{1}{c}{ Variabel } & Sumber \\
\hline & IHSG & \\
& Energy & \\
& Materials & \\
& Consumer Cyclical & Bursa Efek \\
Harga & Consumer Cyclical & Indonesia \\
Saham & Healthcare & Eikon- \\
& Technology & Thompson \\
& Telecommunication & \\
& Utilities & \\
\hline & Sumber: Tabulasi Penulis (2018)
\end{tabular}

Tabel 2 . Statistik Deskriptif

\begin{tabular}{lcccc}
\hline \multicolumn{1}{c}{ Variable } & Mean & $\begin{array}{c}\text { Std. } \\
\text { Dev. }\end{array}$ & Min & Max \\
\hline Energy & 0.2080 & 0.1207 & 0.0012 & 0.4198 \\
Materials & 0.0821 & 0.0336 & 0.0060 & 0.1214 \\
Cons. Cyclical & 0.0727 & 0.0323 & 0.0124 & 0.1051 \\
Cons. Non-Cyclical & 0.2404 & 0.1095 & 0.0042 & 0.3547 \\
Healthcare & 0.3935 & 0.1782 & 0.0006 & 0.6272 \\
Technology & 0.0386 & 0.0237 & 0.0074 & 0.0836 \\
Telecommunication & 0.1826 & 0.0515 & 0.0713 & 0.2575 \\
Utilities & 0.1582 & 0.0744 & 0.0084 & 0.2446 \\
\hline \multicolumn{4}{c}{ Sumber: STATA $14(d i o l a h)$} &
\end{tabular}

Sumber: STATA 14 (diolah)

rentang periode waktu untuk setiap unit observasinya (Gujarati, Damodar, dan Dawn, 2009). Dalam penelitian ini, setiap observasi yang dianalisis merupakan data time series walaupun terdapat beberapa sektor yang berbeda., dikarenakan tujuan utama dari penelitian ini adalah untuk menganalisis

\section{METODOLOGI}

Dalam penelitian ini, dilakukan beberapa pengujian yang bertujuan untuk menganalisis apakah selama periode Ramadhan, saham gabungan (IHSG) maupun saham sektoral mengalami perubahan harga secara signifikan. Namun demikian, sebelum 
masuk kepada olahan data tersebut, maka terlebih dahulu dilakukan beberapa uji yang mencakup uji statistik deskriptif untuk mengetahui profil data yang digunakan di dalam penelitian, kemudian yang selanjutnya adalah uji outlier untuk mengidentifikasi apakah terdapat data yang varians nya besar dan berpotensi menjadikan hasil analisis menjadi bias, uji asumsi klasik (uji multikolinearitas, uji heteroskedastisitas, dan uji autokorelasi), serta uji stasionaritas data dikarenakan analisis pergerakan harga saham menggunakan data time series.

Untuk analisis trend perubahan harga saham gabungan (IHSG) maupun saham sektoral, penelitian ini menggunakan teknik estimasi ARCH GARCH Model. Teknik estimasi untuk menguji sebuah trend pada dasarnya tidak sejalan dengan analisis teknik estimasi Ordinary Least Square, walaupun dalam konteks ini, data yang digunakan adalah sama-sama time-series. Dengan demikian, maka digunakan teknik estimasi ARMA $(1,1)$ - GARCH $(1,1)$ untuk menganalisis dampak dari Bulan Ramadhan terhadap harga saham perusahaanperusahaan yang melantai di Bursa Efek Indonesia (BEI). Spesifikasi matematis dari teknik estimasi ARMA $(1,1)$-GARCH $(1,1)$ adalah sebagai berikut.

$$
\begin{aligned}
& R_{t}=c+\omega_{1} R_{t-1}+\varepsilon_{t}+n_{1} \varepsilon_{t-1}+ \\
& \lambda_{t} D_{\text {ramadhan }}
\end{aligned}
$$$$
\text { di mana }
$$

$$
\varepsilon_{t}^{2} \mid \Omega_{t-1} \sim N\left(0, \sigma_{t}^{2}\right)
$$

$$
\varepsilon_{t}^{2} \mid \Omega_{t-1} \sim N\left(0, \sigma_{t}^{2}\right)
$$

Return $R_{t}$ pada persamaan 3.1 di atas bergantung pada nilai return sebelumnya, $R_{t}$ ${ }_{1}$, danguncangan atau volatilitas sebelumnya, $\varepsilon_{\mathrm{t}-1}$. Sedangkan $\varepsilon_{\mathrm{t}}$ merupakan error-term, sedangkan $c$ merupakan nilai konstan, dan $\omega_{1}, n_{1}$, dan $\lambda$ merupakan nilai koefisien dari masing-masing $\mathrm{R}_{\mathrm{t}-1}, \varepsilon_{\mathrm{t}-1}$ dan $\mathrm{D}_{\text {ramadahan }}$. Dalam penelitian ini variabel dummy $D_{\text {ramadhan }}$ digunakan untuk menggambarkan periode Bulan Ramadhan, di mana rata-rata lama periode Ramadhan mencapai 29 hingga 30 hari. Variabel dummy $D_{\text {ramadhan }}$ diberikan nilai 1 jika pada periode tersebut adalah periode Ramadhan, sedangkan diberikan 0 jika bukan periode Ramadhan. Kemudian $\Omega_{\mathrm{t}-1}$ adalah merupakan variabel pada periode sebelumnya ( $t$-1) serta $\varepsilon^{2}{ }_{\mathrm{t}}$ adalah proses GARCH.

Conditional variance pada persamaan 3.2 merupakan fungsi linear dari akar kuadrat periode sebelumnya $\left(\mathrm{ARCH}, \varepsilon_{\mathrm{t}-1}^{2}\right.$ ) dan merupakan nilai lagged-one conditional variance-nya ( $\mathrm{GARCH}, \sigma^{2}{ }_{t}$ ); selanjutnya $\alpha_{0}$ adalah nilai konstanta intercept, sedangkan nilai estimasi parameter $\alpha_{1}$ dan $\beta_{1}$ merupakan besaran koefisien yang menangkap nilai heteroskedastisitas pada return indeks saham sektoral harian. Satu hal yang sangat penting untuk dipastikan adalah nilai $\alpha_{1}$ dan $\beta_{1}$ bersifat non-negatif, sehingga nilai conditional variance bisa diperoleh. Selain daripada itu, nilai dari $\alpha_{1}+\beta_{1}$ harus kurang dari 1 untuk memastikan conditional variance bersifat stasioner, seperti volatilitas yang bersifat sementara. Jika $\alpha_{1}+\beta_{1}=1$ atau mendekati 1 , maka conditional variancenya bersifat tidak stasioner dan pada saat yang sama data time seris yang digunakan menunjukkan adanya volatilitas yang besar pada harga saham.

\section{Pembahasan dan Analisis Data}

Dalam penelitian ini, model dapat dikatakan robust untuk dapat digunakan menjadi dasar analisis adalah model yang memenuhi karakteristik BLUE. Untuk itu maka dilakukan uji multikolinearitas, uji heteroskedastisitas, uji autokorelasi. Oleh karena data yang digunakan di dalam penelitian ini adalah data time series, maka juga dilakukan uji stasionaritas sebelum diuji pergerakan harga sahamnya sepanjang Bulan Ramadhan. Hasil dari uji multikolinearitas disajikan pada tabel di bawah ini.

Berdasarkan hasil pengujian data di 
Tabel 3. Uji Multikolinearitas

\begin{tabular}{lcc}
\hline \multicolumn{1}{c}{ Variabel } & VIF & $1 /$ VIF \\
\hline IHSG & 1.00000 & 0.998832 \\
Energy & 1.00000 & 0.999939 \\
Materials & 1.00000 & 0.999971 \\
Cons. Cyclical & 1.00000 & 0.999993 \\
Cons. Non-Cyclical & 1.00000 & 0.999965 \\
Healthcare & 1.00000 & 0.999916 \\
Technology & 1.00000 & 0.999610 \\
Telecommunication & 1.00000 & 0.999998 \\
Utilities & 1.00000 & 0.999303 \\
\hline
\end{tabular}

Sumber: STATA 14 (diolah)

atas, dikarenakan nilai VIF nya kurang dari 10 dan nilai dari 1/VIF nya lebih besar dari 0.01 , maka dapat disimpulkan bahwa model tersebut tidak mengandung multikolinearitas. Selanjutnya adalah uji heteroskedastisitas, sebagaimana hasilnya disajikan pada tabel di bawah ini.

Tabel 4. Uji Heteroskedastisitas

\begin{tabular}{lcc}
\hline \multicolumn{1}{c}{ Variabel } & Chi2 & P-Value \\
\hline IHSG & 107.71 & 0.0000 \\
Energy & 31.24 & 0.0000 \\
Materials & 20.58 & 0.0000 \\
Cons. Cyclical & 0.56 & 0.4545 \\
Cons. Non-Cyclical & 88.40 & 0.0000 \\
Healthcare & 61.63 & 0.0000 \\
Technology & 0.53 & 0.4686 \\
Telecommunication & 14.48 & 0.0001 \\
Utilities & 5.09 & 0.0240 \\
\hline \multicolumn{2}{c}{ Sumber: STATA 14 (diolah) }
\end{tabular}

Berdasarkan hasil pengujian data di atas, terdapat dua sektor yang datanya telah memenuhi asumsi homoskedastis sebagaimana ditunjukkan dengan nilai $p$-value lebih dari $5 \%$, yang mencakup sektor consumer cyclical dan technology, yang bermakna bahwa nilai varians dan residualnya sama antar periode waktu. Selebihnya mengandung heteroskedastisitas sebagaimana ditunjukkan bahwa nilai $p$-value nya lebih kecil dari $5 \%$, yang bermakna bahwa nilai varians dan residualnya berbeda antar periode waktu. Kemudian selanjutnya adalah uji autokorelasi sebagaimana disajikan pada tabel di bawah ini.

Tabel 5. Uji Autokorelasi

\begin{tabular}{lcc}
\hline \multicolumn{1}{c}{ Variabel } & Chi2 & P-Value \\
\hline IHSG & 209.017 & 0.0000 \\
Energy & 213.744 & 0.0000 \\
Materials & 213.673 & 0.0000 \\
Cons. Cyclical & 213.752 & 0.0000 \\
Cons. Non-Cyclical & 213.718 & 0.0000 \\
Healthcare & 213.775 & 0.0000 \\
Technology & 211.812 & 0.0000 \\
Telecommunication & 213.575 & 0.0000 \\
Utilities & 213.429 & 0.0000 \\
\hline \multicolumn{2}{c}{ Sumber: STATA 14 (diolah) }
\end{tabular}

Berdasarkan hasil pengujian di atas, seluruh nilai $p$-value dari uji autokorelasi berada di bawah nilai alpha 5\% (sebesar 0.0000), hal ini mengindikasikan bahwa data pada seluruh sektor mengandung autokorelasi. Selanjutnya adalah uji stasionaritas pada analisis data time series penelitian ini.

Dalam penelitian ini, uji stasionaritas dilakukan dengan menggunakan pendekatan Augmented Dickey Fuller Test (ADF). Uji stasionaritas dilakukan pada seluruh sektor yang mencakup Energy, Materials, Consumer Cyclical, Consumer Non-Cyclical, Healthcare, Technology, Telecommunication, dan Utilities. Hasilnya disajikan pada tabel 6 .

Tabel 6 menunjukkan hasil pengujian stasionaritas (unit root test) pada sahamsaham yang listed di Bursa Efek Indonesia (BEI). Seluruh variabel, yang dalam hal ini adalah saham-saham sektoral, menunjukkan bahwa nilai sahamnya stasioner pada turunan pertama ( $1^{\text {st }}$ difference). Oleh karena itu, maka pengujian data time series untuk analisis trend menggunakan data yang telah diturunkan ke level pertama. Dengan demikian, maka analisis pengolahan data 
Tabel 6. Uji Stasionaritas

\begin{tabular}{lcc}
\hline \multicolumn{1}{c}{ Variabel } & ADF & t-stat \\
\hline IHSG & $-31.694 * * *$ & -3.430 \\
Energy & $-31.437 * * *$ & -3.430 \\
Materials & $-31.494 * * *$ & -3.430 \\
Cons. Cyclical & $-31.591 * * *$ & -3.430 \\
Cons. Non-Cyclical & $-31.551 * * *$ & -3.430 \\
Healthcare & $-31.466 * * *$ & -3.430 \\
Technology & $-31.841 * * *$ & -3.430 \\
Telecommunication & $-31.503 * * *$ & -3.430 \\
Utilities & $-31.425 * * *$ & -3.430 \\
\hline Sumber: STATA 14 (diolah) & \\
Keterangan & & \\
*) signifikasni 10\% & & \\
**) signfikansi 5\% & & \\
***) signifikansi 1\% & &
\end{tabular}

berdasarkan hasil uji asumsi klasik maupun uji stasionaritas menunjukkan bahwa data harus ditransformasi. Dalam penelitian ini, data ditransformasi ke dalam bentuk logaritma natural.

Sebelum masuk kepada analisis trend pergerakan harga saham pada Bulan Ramadhan, maka terlebih dahulu diidentifikasi apakah terdapat perbedaan pola pergerakan saham pada Bulan Ramadhan dan bulan-bulan lainnya. Uji beda harga saham dilakukan untuk melihat apakah terdapat perbedaan return (harga) saham saat Bulan Ramadhan dan di luar Bulan Ramadhan. Perbandingan ini dilakukan pada 1 bulan sebelum Ramdhan dan pada saat Bulan Ramadhan. Penggunan bulan pembanding pada 1 bulan sebelum

Tabel 7. Uji Beda Rata-Rata Harga Saham

\begin{tabular}{lcccc}
\hline \multirow{2}{*}{ Sector } & \multicolumn{3}{c}{ Mean (Ramadhan) } & Sig \\
\cline { 2 - 4 } & within & outside & diff & \\
\cline { 2 - 4 } IHSG & 0.0817 & 0.0713 & 0.0104 & 0.2851 \\
energy & 0.2096 & 0.2074 & 0.0022 & 0.2340 \\
materials & 0.0828 & 0.0820 & 0.0009 & 0.3362 \\
cons. cyclical & 0.0734 & 0.0728 & 0.0006 & 0.2324 \\
cons. non-cyclical & 0.2428 & 0.2402 & 0.0026 & 0.3136 \\
healthcare & 0.3961 & 0.3919 & 0.0042 & 0.3089 \\
technology & 0.0394 & 0.0387 & 0.0007 & 0.3793 \\
telecommunication & 0.1839 & 0.1827 & 0.0012 & 0.3099 \\
utilities & 0.1585 & 0.1579 & 0.0006 & 0.1137 \\
\hline
\end{tabular}

Sumber: STATA 14 (diolah)

Tabel 8. Uji Beda Varians Harga Saham

\begin{tabular}{lcccc}
\hline \multicolumn{1}{c}{ Sector } & \multicolumn{4}{c}{$\begin{array}{c}\text { Standard Deviation } \\
\text { (Ramadhan) }\end{array}$} \\
\cline { 2 - 4 } & within & outside & diff & \\
\hline IHSG & 0.0347 & 0.0373 & -0.0026 & 0.2851 \\
energy & 0.1196 & 0.1210 & -0.0014 & 0.2340 \\
materials & 0.0331 & 0.0337 & -0.0007 & 0.3362 \\
cons. cyclical & 0.0319 & 0.0324 & -0.0005 & 0.2324 \\
cons. non-cyclical & 0.1079 & 0.1099 & -0.0020 & 0.3136 \\
healthcare & 0.1754 & 0.1782 & -0.0028 & 0.3089 \\
technology & 0.0240 & 0.0236 & 0.0003 & 0.3793 \\
telecommunication & 0.0505 & 0.0517 & -0.0012 & 0.3099 \\
utilities & 0.0735 & 0.0744 & -0.0008 & 0.1137 \\
\hline \multicolumn{4}{c}{ Sumber: STATA 14 (diolah) } \\
\end{tabular}


Ramadhan ditujukan untuk menghindari adanya dampak post-Ramadhan yang ditengarai dapat berpengaruh terhadap keputusan investor. Hasilnya disajikan pada tabel 7 dan 8 .

Berdasarkan tabel tersebut, rataraat return pada periode bukan Bulan Ramadhan adalah $0.173 \%$, sedangkan pada bulan Ramadhan, rata-rata return-nya adalah $0.171 \%$. Tidak banyak perbedaan sebenarnya, namun dari temuan di atas, dapat disimpulkan bahwa pada perdagangan saham pada Bulan Ramadhan cenderung lebih dinamis jika dibandingkan dengan pada saat Bulan Ramadhan. Hasil Uji NonParametrik Mann Whitney menunjukkan bahwa nilai signifikansi seluruhnya berada di atas $5 \%$, oleh karena itu hal ini menunjukkan bahwa $\mathrm{H}_{0}$ tidak ditolak, atau tidak terdapat perbedaan antara rata-rata pergerakan harga saham pada periode Bulan Ramadhan dan pada bukan Bulan Ramadhan.

Pada dasarnya, harga saham pada periode Ramadhan memberikan rata-rata return yang lebih kecil jika dibandingkan dengan rata-rata harga saham pada saat Bulan Ramadhan. Jika dilihat selisih ratarata harga sahamnya, ditemukan bahwa selisih harga saham pada saat bukan dan pada saat Bulan Ramadhan bernilai positif. Walaupun demikian, terdapat sebuah temuan menarik bahwa ternyata harga saham pada Bulan Ramadhan lebih volatile jika dibandingkan dengan harga saham saat bukan Bulan Ramadhan kecuali pada sektor teknologi yang justru pada Bulan Ramadhan justru variasi pergerakan harga sahamnya relatif lebih kecil jika dibandingkan pada saat bukan Bulan Ramadhan, sebagaimana ditunjukkan pada tabel di bawah ini. Selisih nilai standar deviasi pada bukan Bulan Ramadhan dan pada Bulan Ramadhan bernilai negatif, kecuali pada sektor teknologi.

Analisis volatilitas harga saham dilakukan dengan menggunakan pendekatan ARCH/GARCH. dilakukan pada seluruh sektor yang mencakup Energy, Materials, Consumer Cyclical, Consumer Non-Cyclical, Healthcare, Technology, Telecommunication, dan Utilities. Dalam penelitian ini, hasil pengolahan data tersebut dapat disajikan tabel 9 .

Berdasarkanhasilpengolahandatadiatas, nampak bahwa industri layanan kesehatan cenderung mengalami peningkatan harga saham saat Bulan Ramadhan. Hasil pengujian dengan menggunakan metode ARCH/GARCH menunjukkan bahwa terdapat efek ARCH Lag 1 sebesar 0.9\% dengan tingkat signifikansi sebesar $1 \%$, sedangkan pada GARCH sebesar $0.1 \%$

Tabel 9. Output Pengolahan ARCH GARCH

\begin{tabular}{lcccc}
\hline \multirow{2}{*}{ Sectoral } & \multicolumn{2}{c}{$\operatorname{arch}(1)$} & \multicolumn{2}{c|}{ garch (1) } \\
\cline { 2 - 5 } & coeff & sig & coeff & sig \\
\hline IHSG & 1.030 & 0.030 & 0.124 & 0.626 \\
energy & 1.046 & 0.101 & -0.001 & 0.994 \\
basic materials & 1.056 & 0.028 & -0.004 & 0.966 \\
cons. cyclical & 1.049 & 0.076 & -0.022 & 0.814 \\
cons. non-cyclical & 1.068 & 0.031 & 0.000 & 0.999 \\
healthcare & 0.996 & 0.001 & 0.128 & 0.002 \\
technology & 1.027 & 0.169 & 0.001 & 0.997 \\
telecommunication & 1.143 & 0.000 & -0.008 & 0.945 \\
utilities & 1.086 & 0.050 & -0.098 & 0.360 \\
\hline
\end{tabular}

Sumber: STATA 14 (diolah) 
dengan tingkat signifikansi sebesar $1 \%$. Hal ini menunjukkan bahwa sektor layanan kesehatan (healthcare) secara konsisten mengalami peningkatan harga saham pada saat Bulan Ramadhan. Jika ditinjau lebih lanjut, hasil dari pendalaman pergerakan trend harga saham pada rentang periode 5 hingga 7 tahun. Seluruh perusahan yang listed pada bursa yang berasal dari industri layanan kesehatan (dengan ketersediaan data paling lengkap) diamati trend pergerakan sahamnya khusus pada Bulan Ramadhan di setiap tahunnya. Hasilnya disajikan pada tabel 10 .
2010 hingga 2014, pergerakan return IHSG pada Bulan Ramadhan cenderung fluktuatif, dengan pertumbuhan positif. Namun demikian, jika merujuk ke pergerakan return pada tahun 2008, 2009, 2015, 2016, dan 2018 , rata-rata pertumbuhannya cenderung negatif, sebagaimana disajikan pada grafik di bawah ini.

Pada rentang periode 2008 hingga 2018, rata-rata return IHSG cenderung lebih rendah jika dibandingkan pada bulan-bulan lainnya. Berdasarkan hasil perhitungan ratarata return IHSG berbasis bulanan, nampak bahwa pada Bulan Ramadhan, rata-rata

Tabel 10. Harga Saham Sektor Healthcare

\begin{tabular}{lrrrrr}
\hline \multicolumn{1}{c}{ Perusahaan } & 2014 & \multicolumn{1}{c}{2015} & 2016 & \multicolumn{1}{c}{2017} & 2018 \\
\hline Kalbe Farma & 0.52 & 0.23 & 0.29 & 0.37 & -0.06 \\
Indofarma & 0.31 & 0.53 & 0.57 & -1.84 & -1.87 \\
Millennium & 0.64 & -0.46 & -0.16 & -0.29 & -0.05 \\
Merck & 3.07 & -0.68 & 1.21 & -0.14 & 0.02 \\
Darya-VL & 0.48 & -0.09 & 0.32 & 0.03 & -0.18 \\
Tempo SP & 0.11 & 0.08 & -0.32 & -0.10 & 0.04 \\
Pyridam Farma & -0.10 & 0.09 & -0.30 & -0.28 & 0.17 \\
\hline
\end{tabular}

Sumber: Bursa Efek Indonesia (BEI) 2018

Kemudian jika dirujuk lebih dalam lagi, padasarnya pergerakan return saham pada periode Ramadhan, jika dilihat dari return IHSG, tidak begitu nampak adanya sesuatu yang istimewa. Bahkan pada rentang periode return IHSG adalah $-0.04 \%$, sedangkan rata-rata return pada bulan-bulan lain selain Bulan Ramadhan adalah $0.07 \%$.

Keunikan pergerakan return saham ini mulai nampak jika dilakukan break-down

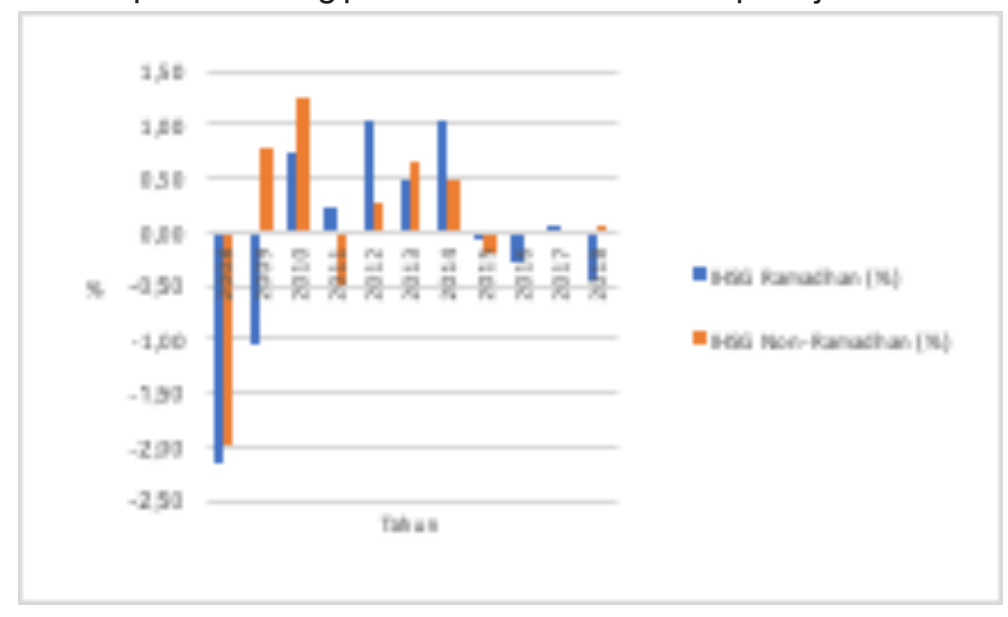

Gambar 1. Rata-Rata Return Saham Sektoral 2008 - 2018 Sumber: STATA 14 (diolah) 


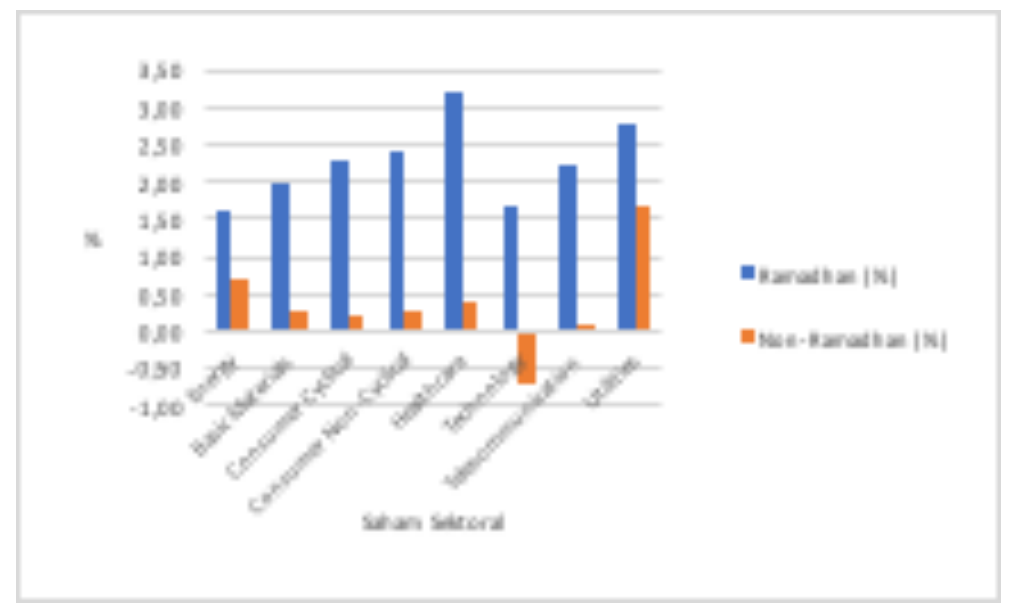

Gambar 2. Rata-Rata Return IHSG 2008 - 2018 Sumber: STATA 14 (diolah)

menurut sektoral pada rentang periode 2008 hingga 2018. Berdasarkan hasil perhitungan rata-rata return saham sektoral sepanjang 2008 hingga 2018, ditemukan bahwa return saham pada periode Bulan Ramadhan cenderung lebih tinggi jika dibandingkan dengan periode pada bulan-bulan lainnya di luar Ramadhan sebagaimana disajikan pada grafik 1 .

Pada Bulan Ramadhan, return saham pada sektor energy meningkat sebesar $1.59 \%$, sedangkan pada bulan lainnya, peningkatannya adalah $0.67 \%$. Selanjutnya untuk sekor basic materials, return saham pada sektor basic materials meningkat sebesar $1.97 \%$ pada Bulan Ramadhan, sedangkan pada bulan lainnya, peningkatannya adalah $0.27 \%$. Kemudian untuk sekor consumer cyclical, return saham pada sektor ini meningkat sebesar $2.30 \%$ pada Bulan Ramadhan, sedangkan pada bulan lainnya, peningkatannyaadalah $0.21 \%$. Yang berikutnya untuk sekor consumer noncyclical, return saham pada sektor tersebut meningkat sebesar $2.41 \%$ pada Bulan Ramadhan, sedangkan pada bulan lainnya, peningkatannya adalah $0.24 \%$. Selanjutnya untuk sekor healthcare, return saham pada sektor ini meningkat sebesar $3.21 \%$ pada Bulan Ramadhan, sedangkan pada bulan lainnya, peningkatannya adalah $0.41 \%$.

Kemudian untuk sekor technology, return saham pada sektor ini meningkat sebesar $1.66 \%$ pada Bulan Ramadhan, sedangkan pada bulan lainnya, return sahamnya justru menurun sebesar $0.69 \%$. Yang selanjutnya untuk sekor telecommunication, return saham pada sektor ini meningkat sebesar $2.25 \%$ pada Bulan Ramadhan, sedangkan pada bulan lainnya, peningkatannya adalah $0.11 \%$. Dan untuk sekor utilities, return saham pada sektor ini meningkat sebesar $2.77 \%$ pada Bulan Ramadhan, sedangkan pada bulan lainnya, peningkatannya adalah $1.70 \%$.

\section{SIMPULAN}

Berdasarkan hasil penelitian ini, maka ditemukan bahwa pergerakan harga saham pada Bulan Ramadhan dan di luar Bulan Ramadhan tidak terjadi perbedaan yang signifikan berdasarkan hasil uji beda dalam penelitian ini. Selain daripadaitu, peningkatan harga saham pada Bulan Ramadhan tidak lebih tinggi jika dibandingkan dengan peningkatan harga saham di luar Bulan Ramadhan, sebagaimana ditunjukkan dari selisih harga saham di luar Bulan Ramadhan yang cenderung lebih tinggi dibandingkan Bulan Ramadhan. Namun demikian, yang menjadikan penelitian ini menarik adalah bahwa varians perdagangan Bulan Ramadhan lebih tinggi, yang bermakna bahwa bahwa pada Bulan Ramadhan, justru 
perdagangan lebih dinamis dibandingkan dengan di luar Bulan Ramadhan.

Dalam penelitian ini, merujuk kepada hasil pengolahan data empiris berbasis pada ARCH GARCH Model, terlihat bahwa hanya sektor healthcare yang mengalami peningkatan harga saham secara signifikan pada periode Bulan Ramadhan, di mana Kalbe Farma merupakan perusahaan yang hampir seluruh periode pengamatan mengalami peningkatan harga saham yang konsisten positif, dan memiliki ratarata saham paling tinggi jika dibandingkan dengan emiten lainnya pada sektor healthcare.

Jika merujuk kepada kinerja return IHSG pada periode Ramadhan, pada dasarnya tidak terdapat perbedaan yang begitu berarti. Hal ini dikarenakan oleh pada rentnag periode 2008 hingga 2018, pergerakan return IHSG nampak begitu fluktuatif. Berdasarkan hasil perhitungan rata-rata return IHSG berbasis bulanan, nampak bahwa pada Bulan Ramadhan, ratarata return IHSG adalah $-0.04 \%$, sedangkan rata-rata return pada bulan-bulan lain selain Bulan Ramadhan adalah $0.07 \%$.

Namun demikian, trend yang sama pada pergerakan return saham mulai nampak jika dilakukan analisis berdasarkan return saham sektoral. Berdasarkan hasil pengolahan data dalam penelitian, nampak bahwa return saham pada sektor healthcare konsisten mengalami peningkatan selama Bulan Ramadhan. Pada rentang periode 2008 2019, return saham pada sektor healthcare meningkat sebesar $3.21 \%$ pada Bulan Ramadhan, sedangkan pada bulan lainnya, peningkatannya adalah $0.41 \%$. Peningkatan return saham untuk sektor healthcare ini tidak terlepas dari kinerja perusahaanperusahaan yang bergerak pada industri layanan kesehatan (healthcare), khususnya pada Bulan Ramadhan. Peningkatan return saham ini didorong oleh ekspektasi positif dari investor memandang peningkatan kineja penjualan perusahaan pada industri healthcare, khususnya pada produk-produk seperti suplemen dan obat resep. Dengan demikian, temuan empiris dalam penelitian ini dapat menjadi masukan strategis bagi pada investor yang ingin memanfaatkan potensi keuntungan pada Bulan Ramadhan, maka investasi sektor healthcare sangat layak untuk dipertimbangkan.

\section{DAFTAR PUSTAKA}

Barnett, V., \& Lewis, T. (1994). Outlier in Statistical Data (3rd ed.). Chichester, UK
Cooper,
D.,
\&
Schindler,
P. (2008).
Business
research methods (10th ed.). New York, McGraw-Hill//rwin. Gujarati, Damodar N., and Dawn C. Porter. (2009). Basic econometrics. Boston, Mass: McGraw-Hill.

Zack (2011). The Handbook of Equity Market Anomalies. Hoboken: John Wlley \& Sons 